\title{
Olfactory Disorders in Post-Acute COVID-19 Syndrome
}

\author{
Laura Araújo ${ }^{1}$, Vanessa Arata ${ }^{1}$ and Ricardo G. Figueiredo ${ }^{1,2,3, *}$ \\ 1 Departamento de Saúde, Universidade Estadual de Feira de Santana (UEFS), \\ Feira de Santana 44036-900, Brazil; laurabeatrizars@hotmail.com (L.A.); vafigueiredo@uefs.br (V.A.) \\ 2 Fundação ProAR, Salvador 41940-455, Brazil \\ 3 Programa de Pós-Graduação em Saúde Coletiva, Universidade Estadual de Feira de Santana (UEFS), \\ Feira de Santana 44036-900, Brazil \\ * Correspondence: rgfigueiredo@uefs.br
}

\section{check for}

updates

Citation: Araújo, L.; Arata, V.; Figueiredo, R.G. Olfactory Disorders in Post-Acute COVID-19 Syndrome. Sinusitis 2021, 5, 116-122. https:// doi.org/10.3390/sinusitis5020012

Academic Editor: Sy Duong-Quy

Received: 3 September 2021

Accepted: 21 September 2021

Published: 24 September 2021

Publisher's Note: MDPI stays neutral with regard to jurisdictional claims in published maps and institutional affiliations.

Copyright: (C) 2021 by the authors Licensee MDPI, Basel, Switzerland. This article is an open access article distributed under the terms and conditions of the Creative Commons Attribution (CC BY) license (https:// creativecommons.org/licenses/by/ $4.0 /)$.

\begin{abstract}
Altered smell is one of the most prevalent symptoms in acute COVID-19 infection. Although most patients recover normal neurosensory function in a few weeks, approximately one-tenth of patients report long-term smell dysfunction, including anosmia, hyposmia, parosmia and phantosmia, with a particularly notable impact on quality of life. In this complex scenario, inflammation and cellular damage may play a key role in the pathogenesis of olfactory dysfunctions and may affect olfactory signaling from the peripheral to the central nervous system. Appropriate management of smell disturbances in COVID-19 patients must focus on the underlying mechanisms and the assessment of neurosensorial pathways. This article aims to review the aspects of olfactory impairment, including its pathophysiology, epidemiology, and clinical management in post-acute COVID-19 syndrome (PACS).
\end{abstract}

Keywords: olfactory dysfunction; anosmia; post-acute COVID-19

\section{Introduction}

Coronavirus 2019 (COVID-19) disease emerged in Wuhan, China, and has subsequently spread worldwide. The pathological agent of COVID-19 is severe acute respiratory syndrome coronavirus 2 (SARS-CoV-2), an enveloped positive single-stranded RNA virus. COVID-19 is a highly transmissible illness with a broad spectrum of clinical manifestations and variable severity degrees depending on age, comorbidities, genetic factors, and basal metabolic index $[1,2]$. Individuals may present with a wide range of symptoms, including fatigue, headache, difficulty breathing, diarrhea, nausea, vomiting, loss of taste and smell, runny nose, and muscle and body ache, often indistinguishable from most respiratory viral infections [3].

COVID-19 can induce abnormalities in taste and smell perception, in both the acute and chronic phases of the disease. Smell disturbances are described as: anosmia-a total absence of smell; hyposmia-a diminished sense of smell; parosmia-distorted perception of an existing odor; and phantosmia-perception of smell when no odor source is present. These neurosensory changes have a pronounced impact on quality of life, as most experiences are malodorous, particularly in the qualitative dysfunctions (parosmia and phantosmia) [4].

Angiotensin-converting enzyme-2 receptors (ACE-2) and transmembrane protease serine 2 (TMPRSS2), expressed in the cells of the nasal epithelium, are known pathways for SARS-CoV-2 entry to the respiratory system [5]. Inflammation and cellular damage may play a key role in the pathogenesis of qualitative olfactory dysfunctions. After its internalization, the virus induces an inflammatory response, undergoing maturation and replication inside the cell, as well as involving the recruitment of immune cells [6,7]. SARSCoV-2 can trigger an unbalanced immune response which overloads the targeted tissues with cytokines and T-cell mediated inflammation [6,7]. The damage caused by the latter may affect olfactory signaling from the peripheral to the central nervous system [8,9]. 
While most survivors will experience a full recovery, follow-up reveals that a high proportion of individuals still report symptoms after the clearance of the acute infection. The terms 'long COVID' ( $>4$ weeks) as well as 'post-acute COVID' ( $>3$ weeks) and 'chronic COVID' (>12 weeks) have been used to describe these ongoing symptoms [8,10].

\section{Epidemiology}

Accumulating evidence indicates that altered smell is one of the most prevalent symptoms in acute COVID-19 infection [11]. In self-report studies, the estimated prevalence of olfactory disorders in acute COVID-19 ranged from 5\% to $85 \%$, depending on disease severity, and seems to be higher than in other respiratory viral infections. Although most of the patients recover normal neurosensory function in a few weeks, approximately one-tenth of patients reported long-term smell dysfunction, including anosmia, hyposmia, parosmia and phantosmia, with a particularly notable impact on quality of life [12].

Qualitative olfactory dysfunctions are often undervalued in the clinical management of COVID-19 infection and are generally underestimated in observational self-report studies. Individuals may experience a range of persistent and prolonged olfactory sequelae in PACS (Table 1). Continued loss of smell after several weeks was reported in 1.7-29\% of patients with COVID-19 requiring hospitalization [13-16]. Disturbed taste and smell were also prevalent after 6 months in approximately one quarter of home-isolated young adults with a milder course of the disease [17]. In a cohort of 467 patients in the United Kingdom followed up at 4-6 weeks, participants with positive SARS-CoV-2 IgM/IgG antibodies reported significantly higher prevalence of longstanding smell loss compared to participants with a negative antibody test, with rates of full resolution of olfactory impairment of $57.7 \%$ and $72.1 \%$, respectively [18]. In addition, female individuals were almost 2.5 times more likely to experience persistent smell loss compared to participants of the male sex, and parosmia was also significantly associated with unresolved smell loss at 4 to 6 weeks follow-up [18].

\section{Pathophysiogenesis of Olfactory Dysfunction}

SARS-CoV-2's route of infection basically comprises two pathways: through cell entry factors such as angiotensin-converting enzyme 2 (ACE2), transmembrane protease serine 2 (TMPRSS2), and furin, or through an endosomal route that does not require previous cleavage of the spike protein (S). ACE2 can act as a primary receptor, and, after virus attachment, the spike protein in its surface is cleaved and dissociated by furin, after which the subunit S2 is cleaved by TMPRSS2, changing the structure of the S2 subunit, which ultimately leads to membrane fusion and viral RNA transferring to host cell cytoplasm. An alternative pathway can also be initiated by ACE2 binding and the internalization process involving clathrin and cathepsin $\mathrm{L}$, and, in this case, the virus releases its genetic material directly after endocytosis, as an alternative independent from TMPRSS2 to invade cells [19].

After entering the mouth through salivary particles, the virus can infect cells in filiform and vallate papillae, lingual epithelium and taste buds, all cells that express ACE2, starting its replication, which in turn causes taste impairment [19]. Other potential targets for cell infection due to ACE2 are vascular endothelial cells and adipocytes in parotid and salivary glands. The damage in these cells affects both blood and nutritional supplies and, indirectly, it can change taste perception [19].

Upper airway mucosa has nasal goblet and ciliated cells expressing ACE2 and TMPRSS2, and these respiratory epithelium cell types may have a role in facilitating SARSCoV-2 infection by storing viral particles [20].

High levels of ACE2 were found in sustentacular cells of the olfactory system, which are in intimate contact with dendrites of olfactory receptor neurons, and also other olfactory epithelium cells such as ductal cells of Bowman's gland, microvillar cells, globose and horizontal basal cells, and olfactory bulb pericytes $[19,21]$. It is hypothesized that infection of mesenchymal stromal and vascular cells in the nose and bulb and their subsequent inflammation affects the neuronal conduction, reduces nutritional and water supplies and, 
therefore, causes the death of olfactory sensory neurons (OSNs) and damage to olfactory bulb function [20] (Figure 1). Although OSNs are surprisingly not an ACE2 expressing tissue, it has already been described that the spike protein can bind to neural cell receptors, possibly due to cell-to-cell transmission through tunneling nanotubes (TNTs), filamentous cellular projections that form a communication and transportation net between cells [19].

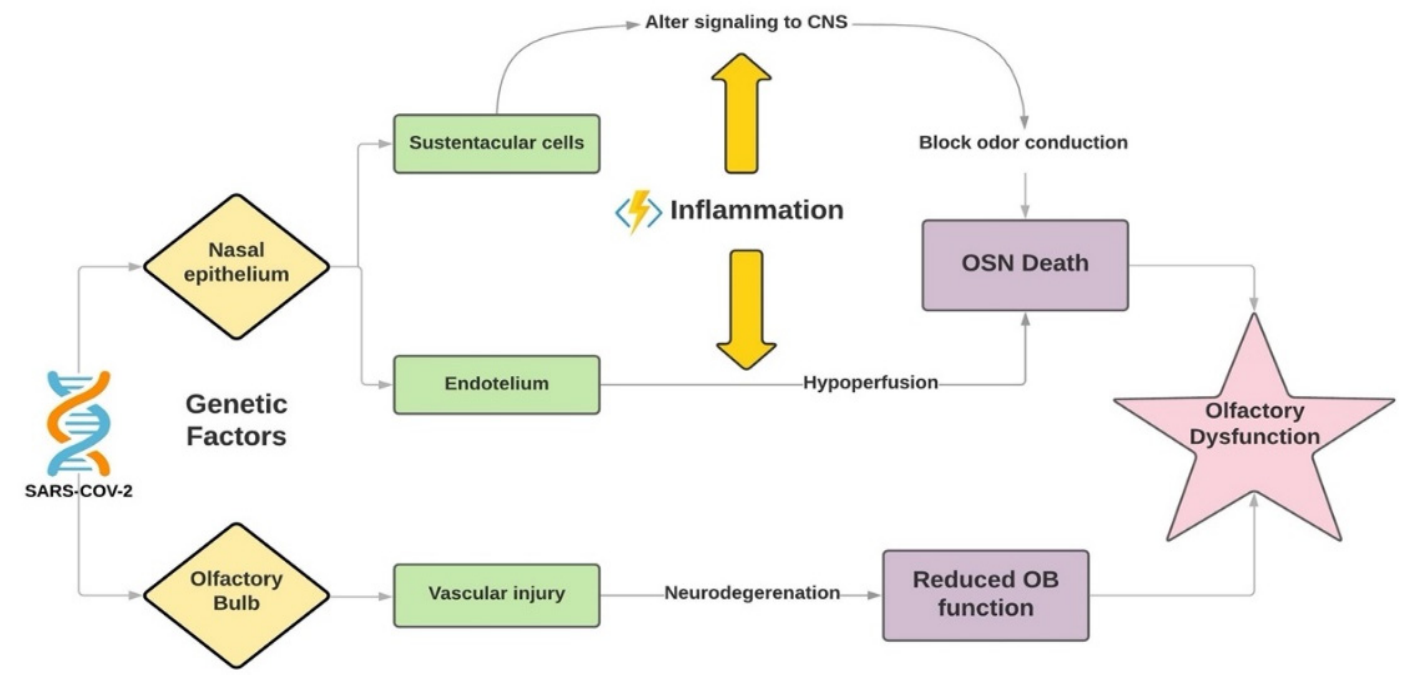

Figure 1. Pathogenesis of olfactory dysfunction. Infection of mesenchymal stromal and vascular cells in the nose and bulb and their subsequent inflammation affect the neuronal conduction, reduce nutritional and water supplies and, therefore, cause the death of olfactory sensory neurons (OSNs) and damage to olfactory bulb function. SARS-COV-2 indicates severe acute respiratory syndrome coronavirus 2; CNS, central nervous system; OB, olfactory bulb; OSN, olfactory sensory neurons.

Neuropilin-1 represents another host factor that facilitates SARS-CoV-2 entry, and its presence was detected in mitral cells of the olfactory bulb, but not in the $\mathrm{OE}$, and the virus may enter the central nervous system (CNS) through retrograde axonal transport from the nasal cavity in a process mediated by ACE2, TMPRSS2 and nicotinic receptors [22]. SARS-CoV-2 uses olfactory neurons to approach the CNS, and similar mechanisms were described for SARS-CoV-1, MERS- $\mathrm{CoV}$, and HCoV-OCR43. The neuronal damage in axons, the death of neurons and microhemorrhages in the bulb may extend the period of smell disturbances [22].

To sum up, these are the ways through which SARS-CoV-2 may cause olfactory dysfunction: conductive dysfunction, by mechanically blocking smell from reaching neuroepithelium; sensorineural dysfunction by attacking directly or indirectly olfactory neuroepithelium or OSNs; and central dysfunction, by affecting bulb neurons [22].

\section{Smell Dysfunction in PACS}

Smell dysfunction can occur in the context of various infectious viral diseases [23]. Alteration of smell can be categorized into two distinct types: quantitative and qualitative, and subcategorized in total/complete or partial/incomplete, as well as in unilateral or bilateral [23]. Quantitative loss is seen in anosmia and hyposmia, while qualitative loss is noted in parosmia and phantosmia [24].

Anosmia and hyposmia can be assessed by running olfactory tests such as "le nez du vin" or "scratch and sniff" pads containing variable odorant samples [23,25]. Notably, hyposmia and anosmia in infectious diseases are distinguished from nasal inflammation by their lack of seasonal variance, and sometimes permanent length of stay [23].

In contrast to common upper airways infection, rhinorrhea or nasal congestion are less associated with anosmia in COVID -19; however, it can affect the central nervous system, as observed in an 18-FDG PET/CT study, in which a reduction in metabolic activity was reported in the left orbitofrontal cortex, and it can be associated with edema of the olfactory 
bulb in MRI [26-28]. Anosmia can lead to suspicion of COVID-19 diagnosis, as it can be the only clinical feature present [29].

Hyposmia was reported in a study in Padua as an isolated or more prominent symptom of SARS-CoV-2 infection, often associated with hypogeusia [25]. Hyposmia and parosmia can be persistent olfactory dysfunctions in PACS [28].

Parosmia and phantosmia are distortions in smell perception. Parosmia is a disorder in which an odor is perceived as a different smell, either pleasant—euosmia—or unpleasanttroposmia [25]. Troposmia is often referred to as a burned, foul or rotten smell [27]. In an 18-FDG PET/CT study, the activity in the secondary olfactory cortex was preserved in a patient presenting parosmia post anosmia after COVID-19 infection [27]. In another study, reduced olfactory bulb activity was associated with parosmia [27]. Parosmia and anosmia can be related, and loss of smell can evolve into parosmia in the context of SARS-CoV-2 infection [18].

Parosmia can be related to peripheral and central injuries by SARS-CoV-2, since it can affect OSNs and olfactory centers in the bulb [27]. The growth of new olfactory axons can occur in a non-organized manner and, as a consequence, it prolongs parosmia [18]. Data concerning post-infectious parosmia point to a poorer prognostic value towards the recuperation of smell ability, although olfactory training can help in the recovery of smell [18].

In phantosmia, the smell sensation is generated even in the absence of odors [24]. Smell disturbances can affect taste perception [30]. Taste dysfunctions post COVID-19 infection can also be categorized as qualitative or quantitative. Qualitative taste alterations are known as dysgeusia, whereas quantitative ones are referred to as hypogeusia, in which taste is decreased, and ageusia, in which taste sensation is non-existent [20]. The inflammatory response may cause reparable damage to the taste buds, and as a consequence, a short recovery time can be expected. An unbalanced immune response may also be an agent for a bad prognosis in sensory loss, since the T-cell response is present in sialadenitis and xerostomia [20]. Additionally, distortion in chemosensory perception, such as parosmia or dysgeusia, may increase the probability of long-term smell and/or taste loss and longer COVID-19 symptoms [18].

\section{Clinical Management Considerations}

Despite overcoming systemic inflammation and respiratory distress in the acute phase of COVID-19 infection, some patients present prolonged inflammation and tissue damage. Appropriate management of smell disturbances in COVID-19 patients must focus on the underlying mechanisms and the assessment of neurosensorial pathways. Although most COVID-19-related acute olfactory dysfunctions improve spontaneously, treatment for persistent smell symptoms may be reasonable when impairment lingers beyond 2 weeks [31]. However, the efficacy of available treatment in PACS remains unclear.

Olfactory rehabilitation has been described as an effective method for restoring the sense of smell in post-infectious olfactory dysfunction (PIOD). Olfactory training is a simple and safe strategy defined as repeated and conscious sniffing of a set of odorants, for 15-20 s each, at least twice a day [32]. Additionally, the conscious focus on odors, in addition to human olfactory ecology including social and physical environment triggers, may effectively stimulate the neurosensorial system and enhance olfactory performance [33]. A retrospective German study of 153 patients with PIOD showed clinically relevant improvements in overall quantitative and qualitative function upon receiving olfactory training (OT). Additionally, the presence of parosmia was associated with significant improvement of olfactory performance after OT [34].

Oral and nasal corticosteroids may be used to control a potential inflammatory component in PIOD; however, current evidence does not support the routine administration of systemic corticosteroids in this scenario due to safety concerns. Additionally, unless inflammatory features in endoscopic or imaging evaluation are detected, it is improbable that corticosteroids would be helpful. [31]. A recent randomized controlled trial (RCT) 
failed to prove the superiority of mometasone furoate topical nasal therapy over OT in the treatment of post COVID-19 anosmia. [35]. Notably, intranasal corticosteroid therapy in patients with allergic rhinitis and concomitant COVID-19 infection have recently been reviewed in an ARIA-EAACI position paper. These have been shown to be safe and should be considered, at the recommended dose, on a case-by-case basis [36].

Table 1. Prevalence of olfactory dysfunction in post-acute COVID-19 syndrome.

\begin{tabular}{|c|c|c|c|c|c|c|}
\hline Author & Country & Setting & Time (Days) & Population & $n$ & $\begin{array}{c}\text { Prevalence of Ol- } \\
\text { factory/Gustatory } \\
\text { Dysfunction }\end{array}$ \\
\hline Garrigues 2020 [13] & France & $\begin{array}{l}\text { Cross sectional, } \\
\text { single center }\end{array}$ & 110.9 & Hospitalized & 120 & Anosmia (13.3\%) \\
\hline Chopra 2020 [14] & United States & $\begin{array}{l}\text { Prospective cohort, } \\
\text { multicenter }\end{array}$ & 60 & Hospitalized & 488 & $\begin{array}{c}\text { Loss of taste and/or } \\
\text { smell }(28 \%)\end{array}$ \\
\hline $\begin{array}{c}\text { Rosales-Castillo } \\
2020 \text { [15] }\end{array}$ & Spain & $\begin{array}{c}\text { Retrospective } \\
\text { cohort, single } \\
\text { center }\end{array}$ & 50.8 & Hospitalized & 118 & Anosmia (1.7\%) \\
\hline Jacobs 2020 [16] & United States & $\begin{array}{l}\text { Prospective cohort, } \\
\text { single center }\end{array}$ & 35 & Hospitalized & 183 & Lack of smell $(9.3 \%)$ \\
\hline Daher 2020 [37] & Germany & $\begin{array}{l}\text { Prospective cohort, } \\
\text { single center }\end{array}$ & 42 & Hospitalized & 33 & Loss of smell $(12 \%)$ \\
\hline Klein 2020 [38] & Israel & $\begin{array}{l}\text { Prospective cohort, } \\
\text { single center }\end{array}$ & 180 & $\begin{array}{c}\text { Hospitalized } \\
(5.5 \%) \text { and } \\
\text { home-isolated }\end{array}$ & 112 & $\begin{array}{l}\text { Smell changes } \\
\qquad(9.8 \%)\end{array}$ \\
\hline $\begin{array}{l}\text { Moreno-Pérez } \\
2021 \text { [39] }\end{array}$ & Spain & $\begin{array}{l}\text { Prospective cohort, } \\
\text { multicenter }\end{array}$ & $112-126$ & $\begin{array}{c}\text { Hospitalized } \\
(58.2 \%) \text { and } \\
\text { home-isolated }\end{array}$ & 277 & $\begin{array}{c}\text { Anosmia-dysgeusia } \\
(21 \%)\end{array}$ \\
\hline Seessle 2021 [40] & Germany & $\begin{array}{l}\text { Prospective cohort, } \\
\text { single center }\end{array}$ & 360 & $\begin{array}{c}\text { Hospitalized } \\
(32.3 \%) \text { and } \\
\text { home-isolated }\end{array}$ & 96 & Anosmia (20.8\%) \\
\hline Tenford 2020 [41] & United States & $\begin{array}{l}\text { Cross sectional, } \\
\text { multicenter }\end{array}$ & $14-21$ & Home-isolated & 270 & Loss of smell $(27 \%)$ \\
\hline $\begin{array}{l}\text { Boscolo-Rizzo } \\
2020 \text { [42] }\end{array}$ & Italy & $\begin{array}{l}\text { Cross sectional, } \\
\text { single center }\end{array}$ & 28 & Home-isolated & 187 & $\begin{array}{l}\text { Altered sense of } \\
\text { smell or taste } \\
\quad(51.3 \%)\end{array}$ \\
\hline Paderno 2020 [43] & Italy & $\begin{array}{l}\text { Prospective cohort, } \\
\text { multicenter }\end{array}$ & 30 & Home-isolated & 151 & $\begin{array}{c}\text { Olfactory } \\
\text { dysfunction }(17.7 \%)\end{array}$ \\
\hline $\begin{array}{c}\text { Valiente-De Santis } \\
2020[44]\end{array}$ & Spain & $\begin{array}{l}\text { Prospective cohort, } \\
\text { single center }\end{array}$ & 84 & Home-isolated & 108 & Anosmia (9.3\%) \\
\hline Otte 2020 [45] & Germany & $\begin{array}{l}\text { Cross sectional, } \\
\text { single center }\end{array}$ & 56 & Home-isolated & 80 & Hyposmia (45.1\%) \\
\hline Blomberg 2021 [17] & Norway & $\begin{array}{l}\text { Prospective cohort, } \\
\text { multicenter }\end{array}$ & 168 & Home-isolated & 247 & $\begin{array}{c}\text { Disturbed } \\
\text { taste/smell (27\%) }\end{array}$ \\
\hline
\end{tabular}

COVID-19 indicates coronavirus disease 2019; Time, time to assessment in days; $n$, sample size.

Author Contributions: L.A., V.A., R.G.F. contributed equally to this work. All authors have read and agreed to the published version of the manuscript.

Funding: This research received no external funding.

Conflicts of Interest: The authors declare no conflict of interest. 


\section{References}

1. Escandón, K.; Rasmussen, A.L.; Bogoch, I.I.; Murray, E.J.; Escandón, K.; Popescu, S.V.; Kindrachuk, J. COVID-19 false dichotomies and a comprehensive review of the evidence regarding public health, COVID-19 symptomatology, SARS-CoV-2 transmission, mask wearing, and reinfection. BMC Infect. Dis. 2021, 21, 1-47. [CrossRef]

2. Cevik, M.; Kuppalli, K.; Kindrachuk, J.; Peiris, M. Virology, transmission, and pathogenesis of SARS-CoV-2. BMJ 2020, 371, 1-6.

3. Centers for Disease Control and Prevention. Interim Clinical Guidance for Management of Patients with Confirmed Coronavirus Disease (COVID-19). Available online: https:/ / www.cdc.gov / coronavirus/2019-ncov/hcp/clinical-guidance-managementpatients.html (accessed on 21 August 2021).

4. Keller, A.; Malaspina, D. Hidden consequences of olfactory dysfunction: A patient report series. BMC Ear Nose Throat Disord. 2013, 13. [CrossRef]

5. Bourgonje, A.R.; Abdulle, A.E.; Timens, W.; Hillebrands, J.L.; Navis, G.J.; Gordijn, S.J.; Bolling, M.C.; Dijkstra, G.; Voors, A.A.; Osterhaus, A.D.; et al. Angiotensin-converting enzyme 2 (ACE2), SARS-CoV-2 and the pathophysiology of coronavirus disease 2019 (COVID-19). J. Pathol. 2020, 251, 228-248. [CrossRef]

6. Hamming, I.; Timens, W.; Bulthuis, M.L.C.; Lely, A.T.; Navis, G.J.; van Goor, H. Tissue distribution of ACE2 protein, the functional receptor for SARS coronavirus. A first step in understanding SARS pathogenesis. J. Pathol. 2004, 203, 631-637. [CrossRef] [PubMed]

7. Wu, Z.; McGoogan, J.M. Characteristics of and Important Lessons from the Coronavirus Disease 2019 (COVID-19) Outbreak in China: Summary of a Report of 72314 Cases from the Chinese Center for Disease Control and Prevention. JAMA J. Am. Med. Assoc. 2020, 323, 1239-1242. [CrossRef] [PubMed]

8. Shah, W.; Hillman, T.; Playford, E.D.; Hishmeh, L. Managing the long term effects of covid-19: Summary of NICE, SIGN, and RCGP rapid guideline. BMJ 2021, 372, n136. [CrossRef] [PubMed]

9. Tsuchiya, H. Oral symptoms associated with COVID-19 and their pathogenic mechanisms: A literature review. Dent. J. 2021, 9, 32. [CrossRef] [PubMed]

10. Greenhalgh, T.; Knight, M.; A'Court, C.; Buxton, M.; Husain, L. Management of post-acute covid-19 in primary care. BMJ 2020, 370, m3026. [CrossRef]

11. Printza, A.; Katotomichelakis, M.; Valsamidis, K.; Metallidis, S.; Panagopoulos, P.; Panopoulou, M.; Petrakis, V.; Constantinidis, J. Smell and Taste Loss Recovery Time in COVID-19 Patients and Disease Severity. J. Clin. Med. 2021, 10, 966. [CrossRef]

12. Parma, V.; Ohla, K.; Veldhuizen, M.G.; Niv, M.Y.; Kelly, C.E.; Bakke, A.J.; Cooper, K.W.; Bouysset, C.; Pirastu, N.; Dibattista, M. More than smell-COVID-19 is associated with severe impairment of smell, taste, and chemesthesis. Chem. Senses 2020, 45, 609-622. [CrossRef]

13. Garrigues, E.; Janvier, P.; Kherabi, Y.; Le Bot, A.; Hamon, A.; Gouze, H.; Doucet, L.; Berkani, S.; Oliosi, E.; Mallart, E.; et al. Post-discharge persistent symptoms and health-related quality of life after hospitalization for COVID-19. J. Infect. 2020, 81, e4-e6. [CrossRef] [PubMed]

14. Chopra, V.; Flanders, S.A.; O'Malley, M.; Malani, A.N.; Prescott, H.C. Sixty-day outcomes among patients hospitalized wed. Am. J. Physiol. Cell Physiol. 2020, 319, 945.

15. Rosales-Castillo, A.; García de los Ríos, C.; Mediavilla García, J.D. Persistent symptoms after acute COVID-19 infection: Importance of follow-up. Med. Clínica Engl. Ed. 2021, 156, 35-36.

16. Jacobs, L.G.; Paleoudis, E.G.; Di Bari, D.L.; Nyirenda, T.; Friedman, T.; Gupta, A.; Rasouli, L.; Zetkulic, M.; Balani, B.; Ogedegbe, C.; et al. Persistence of symptoms and quality of life at 35 days after hospitalization for COVID-19 infection. PLoS ONE 2020, 15, e0243882. [CrossRef] [PubMed]

17. Blomberg, B.; Mohn, K.G.I.; Brokstad, K.A.; Zhou, F.; Linchausen, D.W.; Hansen, B.A.; Lartey, S.; Onyango, T.B.; Kuwelker, K.; Sævik, M.; et al. Long COVID in a prospective cohort of home-isolated patients. Nat. Med. 2021, 23, 1-7.

18. Makaronidis, J.; Firman, C.; Magee, C.G.; Mok, J.; Balogun, N.; Lechner, M.; Carnemolla, A.; Batterham, R.L. Distorted chemosensory perception and female sex associate with persistent smell and/or taste loss in people with SARS-CoV-2 antibodies: A community based cohort study investigating clinical course and resolution of acute smell and/or taste loss in people. BMC Infect. Dis. 2021, 21, 221. [CrossRef] [PubMed]

19. Okada, Y.; Yoshimura, K.; Toya, S.; Tsuchimochi, M. Pathogenesis of taste impairment and salivary dysfunction in COVID-19 patients. Jpn. Dent. Sci. Rev. 2021, 57, 111-122. [CrossRef]

20. Brann, D.H.; Tsukahara, T.; Weinreb, C.; Lipovsek, M.; Van Den Berge, K.; Gong, B.; Chance, R.; Macaulay, I.C.; Chou, H.J.; Fletcher, R.B.; et al. Non-neuronal expression of SARS-CoV-2 entry genes in the olfactory system suggests mechanisms underlying COVID-19-associated anosmia. Sci. Adv. 2020, 6, eabc5801. [CrossRef]

21. Wang, F.; Kream, R.M.; Stefano, G.B. Long-term respiratory and neurological sequelae of COVID-19. Med. Sci. Monit. 2020, 26, e928996. [PubMed]

22. Kapoor, D.; Verma, N.; Gupta, N.; Goyal, A. Post Viral Olfactory Dysfunction After SARS-CoV-2 Infection: Anticipated Postpandemic Clinical Challenge. Indian J. Otolaryngol. Head Neck Surg. 2021, 1-8. [CrossRef]

23. Doty, R.L. The olfactory system and Its disorders. Semin Neurol. 2009, 29, 74-81. [CrossRef] [PubMed]

24. Rashid, R.A.; Alaqeedy, A.A.; Al-Ani, R.M. Parosmia Due to COVID-19 Disease: A 268 Case Series. Indian J. Otolaryngol. Head Neck Surg. 2021, 1-8. [CrossRef] 
25. Marchese-Ragona, R.; Ottaviano, G.; Piero, N.; Vianello, A.; Miryam, C. Sudden hyposmia as a prevalent symptom of COVID-19 infection. medRxiv 2020. [CrossRef]

26. Guedj, E.; Campion, J.Y.; Dudouet, P.; Kaphan, E.; Bregeon, F.; Tissot-Dupont, H.; Guis, S.; Barthelemy, F.; Habert, P.; Ceccaldi, M.; et al. 18F-FDG brain PET hypometabolism in patients with long COVID. Eur. J. Nucl. Med. Mol. Imaging 2021, 48, 2823-2833. [CrossRef] [PubMed]

27. Yousefi-Koma, A.; Haseli, S.; Bakhshayeshkaram, M.; Raad, N.; Karimi-Galougahi, M. Multimodality Imaging With PET/CT and MRI Reveals Hypometabolism in Tertiary Olfactory Cortex in Parosmia of COVID-19. Acad. Radiol. 2021, 28, 749-751. [CrossRef] [PubMed]

28. Xydakis, M.S.; Albers, M.W.; Holbrook, E.H.; Lyon, D.M.; Shih, R.Y.; Frasnelli, J.A.; Pagenstecher, A.; Kupke, A.; Enquist, L.W.; Perlman, S. Post-viral effects of COVID-19 in the olfactory system and their implications. Lancet Neurol. 2021, $20,753-761$. [CrossRef]

29. Mehraeen, E.; Behnezhad, F.; Salehi, M.A.; Noori, T.; Harandi, H.; SeyedAlinaghi, S.A. Olfactory and gustatory dysfunctions due to the coronavirus disease (COVID-19): A review of current evidence. Eur. Arch. Oto-Rhino-Laryngol. 2021, 278, 307-312. [CrossRef]

30. Crook, H.; Raza, S.; Nowell, J.; Young, M.; Edison, P. Long covid-Mechanisms, risk factors, and management. BMJ $2021,374$. [CrossRef]

31. Whitcroft, K.L.; Hummel, T. Olfactory Dysfunction in COVID-19: Diagnosis and Management. JAMA J. Am. Med. Assoc. 2020, 323, 2512-2514. [CrossRef]

32. Hummel, T.; Reden, K.R.J.; Hähner, A.; Weidenbecher, M.; Hüttenbrink, K.B. Effects of olfactory Training in patients with olfactory loss. Laryngoscope 2009, 119, 496-499. [CrossRef]

33. Oleszkiewicz, A.; Heyne, L.; Sienkiewicz-Oleszkiewicz, B.; Cuevas, M.; Haehner, A.; Hummel, T. Odours count: Human olfactory ecology appears to be helpful in the improvement of the sense of smell. Sci. Rep. 2021, 11, 16888. [CrossRef] [PubMed]

34. Liu, D.T.; Sabha, M.; Damm, M.; Philpott, C.; Oleszkiewicz, A.; Hähner, A.; Hummel, T. Parosmia is Associated with Relevant Olfactory Recovery After Olfactory Training. Laryngoscope 2021, 131, 618-623. [CrossRef] [PubMed]

35. Abdelalim, A.A.; Mohamady, A.A.; Elsayed, R.A.; Elawady, M.A.; Ghallab, A.F. Corticosteroid nasal spray for recovery of smell sensation in COVID-19 patients: A randomized controlled trial. Am. J. Otolaryngol. 2021, 42, 102884. [CrossRef] [PubMed]

36. Bousquet, J.; Akdis, C.A.; Jutel, M.; Bachert, C.; Klimek, L.; Agache, I.; Ansotegui, I.J.; Bedbrook, A.; Bosnic-Anticevich, S.; Canonica, G.W.; et al. Intranasal corticosteroids in allergic rhinitis in COVID-19 infected patients: An ARIA-EAACI statement. Allergy Eur. J. Allergy Clin. Immunol. 2020, 75, 2440-2444. [CrossRef] [PubMed]

37. Daher, A.; Balfanz, P.; Cornelissen, C.; Müller, A.; Bergs, I.; Marx, N.; Müller-Wieland, D.; Hartmann, B.; Dreher, M.; Müller, T. Follow up of patients with severe coronavirus disease 2019 (COVID-19): Pulmonary and extrapulmonary disease sequelae. Respir. Med. 2020, 174, 106197. [CrossRef]

38. Hadar, K.; Kim, A.; Noam, K.; Yuval, B.; Ran, N.P.; Mordechai, M.; Sarah, I.; Masha, Y.N. Onset, duration, and persistence of taste and smell changes and other COVID-19 symptoms: Longitudinal study in Israeli patients. MedRxiv 2020. [CrossRef]

39. Moreno-Pérez, O.; Merino, E.; Leon-Ramirez, J.M.; Andres, M.; Ramos, J.M.; Arenas-Jiménez, J.; Asensio, S.; Sanchez, R.; Ruiz-Torregrosa, P.; Galan, I.; et al. Post-acute COVID-19 syndrome. Incidence and risk factors: A Mediterranean cohort study. J. Infect. 2021, 82, 378-383. [CrossRef]

40. Seeßle, J.; Waterboer, T.; Hippchen, T.; Simon, J.; Kirchner, M.; Lim, A.; Müller, B.; Merle, U. Persistent symptoms in adult patients one year after COVID-19: A prospective cohort study. Clin. Infect. Dis. 2021. [CrossRef]

41. Tenforde, M.W.; Kim, S.S.; Lindsell, C.J.; Erica, B.R.; Nathan, I.S.; Clark, F.D.; Kevin, W.G.; Heidi, L.E.; Jay, S.S.; Howard, A.S.; et al. Symptom duration and risk factors for delayed return to usual health among outpatients with COVID-19 in a multistate health care systems network-United States, March-June 2020. MMWR Morb. Mortal Wkly. Rep. 2020, 69, 993-998. [CrossRef]

42. Boscolo-Rizzo, P.; Borsetto, D.; Fabbris, C.; Spinato, G.; Frezza, D.; Menegaldo, A.; Mularoni, F.; Gaudioso, P.; Cazzador, D.; Marciani, S.; et al. Evolution of Altered Sense of Smell or Taste in Patients With Mildly Symptomatic COVID-19. JAMA Otolaryngol. Head Neck Surg. 2020, 146, 729-732. [CrossRef]

43. Paderno, A.; Mattavelli, D.; Rampinelli, V.; Grammatica, A.; Raffetti, E.; Tomasoni, M.; Gualtieri, T.; Taboni, S.; Zorzi, S.; Del Bon, F.; et al. Olfactor and gustatory outcomes in COVID-19: A prospective evaluation in nonhospitalized subjects. Otolaryngol.-Head Neck Surg. 2020, 163, 1144-1149. [CrossRef] [PubMed]

44. Lucía, V.D.S.; Inés, P.C.; Beatriz, S.; Gracia, E.G.; Juan, D.R.M.; Antonio, P.; Ignacio, M.G.; Marcial, D.F.; Manuel, C.; Francisco, O; i et al. Clinical and immunoserological status 12 weeks after infection with COVID-19: Prospective observational study. MedRxiv 2020. [CrossRef]

45. Otte, M.S.; Eckel, H.N.C.; Poluschkin, L.; Klussmann, J.P.; Luers, J.C. Olfactory dysfunction in patients after recovering from COVID-19. Acta Otolaryngol. 2020, 140, 1032-1035. [CrossRef] [PubMed] 